\title{
Is There Moral Hazard in Islamic Rural Bank Financing?
}

IQTISHADIA

12,2

\author{
Adelia Oktarina \\ Bogor Agricultural Unniversity \\ adeliaoktarina3o@gmail.com \\ Idqan Fahmi \\ Bogor Agricultural Unniversity \\ ifahmi@mb.ipb.ac.id \\ Irfan Syauqi Beik \\ Bogor Agricultural Unniversity \\ qibeiktop@yahoo.com
}

\begin{abstract}
The credit market was identical to asymmetric information in it, both conventional and sharia credit markets. One of the forms of this asymmetric information was moral hazard. This study aimed to identify the existence of moral hazard in credit market (financing) by comparing the customer conditions in Islamic rural bank and conventional rural bank. This study also intended to identify the factors influencing the moral hazard. The analysis used was logistic regression method. The result showed that Islamic rural bank had a bigger potential to experience moral hazard compared to the conventional customers. Generally, the factors which influence the moral hazard such as age, business conditions, amount of financing, length of financing, and type of bank.
\end{abstract}

\section{Keywords:}

Islamic rural bank, Factors, Logistic regression, Moral hazard, Solutions.

\section{INTRODUCTION}

Banking sector had positive contribution into economy. It means there was positive performance of banking sector. As intermediary institution, this performance was expected to be able to decrease economic disparities. Therefore, accelerating economic growth can occur. The big effect of banking toward national economic makes bank sector as one of sectors that obtain big attention from government. One of government's attentions was constitution number 7 in 1992 that underlies banks which used interest system or it is known as Islamic bank.

The emergence of constitution number 7 in 1992 about Banking marked out the emergence of dual banking system in Indonesia. In the beginning, banking in Indonesia only knew interest rate. The needs of Muslims in bank Dor : 10.21043/iqtishadia.v12i2.3975 transaction which according to Islamic law encouraged the government to 
IQTISHADIA

12,2

120

validate the existence of profit sharing banking (Islamic bank) in Indonesia. The high attention of people toward the presence of sharia bank encouraged conventional bank to do the bank service based on sharia, which was called Islamic unit.In additional, some of Islamic unit became the bank of its own. These separations occurred because fundamental differences in operational system of Islamic bank and conventional ones. Beside, core bank or conventional bank perceive that the existence of Islamic unit was as competitor bank.

It proves there was rivalry enhancement between banks after the emergence of Islamic bank in banking industry. This condition was common situation considering bank is also commercial institution that will give effort to maximize the profit (Nuryakin \& Warjiyo, 2006). This rivalry eventually would become win-win solution for each bank. With competitor banks, banks will have motivation to increased performance so they are able to increase the profit of bank. One of competitions among banks in maximizing the effort emerges in rivalry in distribution of financing. Nuryakin and Warjiyo (2006) stated that the enhancement of the amount of credit offer by ban will encourage other banks to increase credit offer. Financing to deposit ratio (FDR) in Islamic bank and loan to deposit ratio (LDR) in conventional bank can depict trend or tendency of bank in distribution of financing (Figure 1).

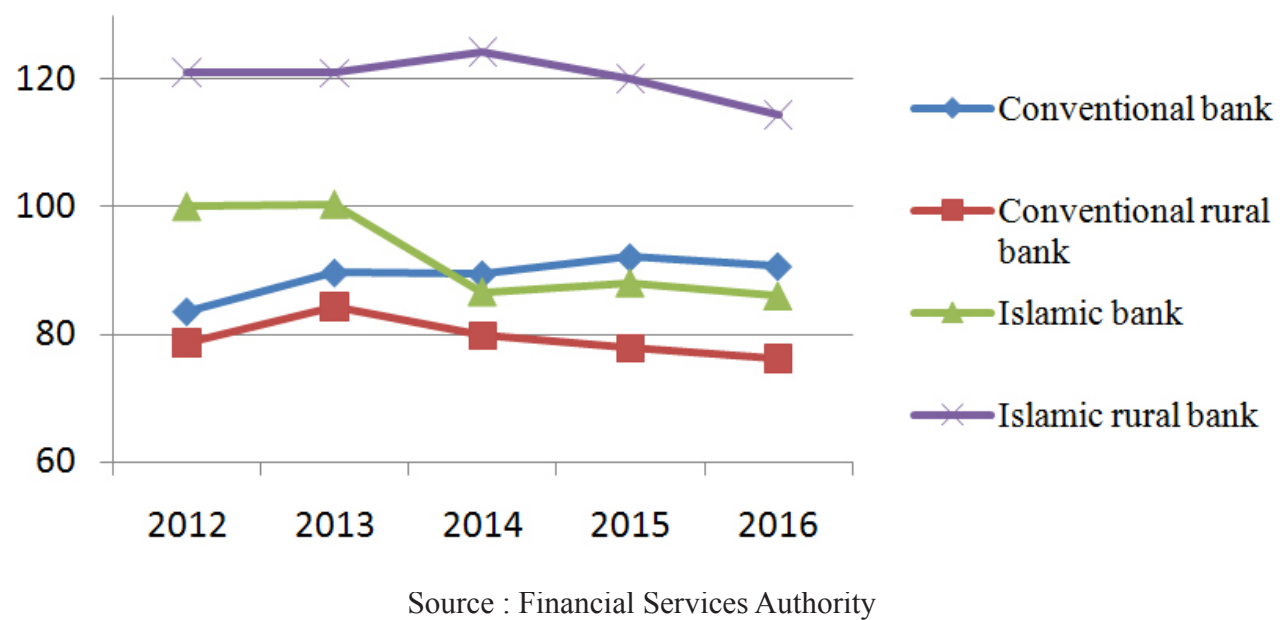

Figure 1 Financing Ratio in Indonesia 2012-2016

Figure 1 showed that FDR of sharia bank is relatively higher than LDR of conventional bank.

This condition disputed the explanation of Trad et al. (2016) who said that Islamic bank had lower financing level than conventional bank. Islamic bank and Islamic unit had high enough FDR rate in 2012 to 2013, then it decreased in 2014. It is the impact of economic slowdown in Indonesia in 2013 
and unstable of real sector. Meanwhile, society of precautionary motives tend to increase that impact to the growth of third party fund which are not able to compensated the financing. The decrease of FDR had to be conducted to be able to maintain liquidity of bank at that time. In 2014, Islamic bankcould maintain stability of their liquidity.

The other way, conventional bank tent to increased LDR in in the end of 2013 so that it causes the pressure of liquidity risk increased. However, in 2014, conventional bank could stabilize third party fund accumulation so that it was able to increase LDR. In the other hand, LDR of conventional rural bank was relatively in safe condition limit, in which obtained financing was not more than collected third party fund. Otherwise, FDR of Islamic rural bank (IRB) was still in highest position. It was bigger than 100\%, it means that financing amounted by IRB was bigger than third party fund that they can collected. This high distribution of financing will impact on disrupted bank liquidity so that bank had to allocate the capital or asset of bank in order to maintain the stability of liquidity. Even though it had decrease in capital, it did not limit financing distribution by the bank (Armanto, 2005). The aim of maximizing the profit becomes big motivation for IRB in giving big financing. However, financing which does not support by good quality of financing will increase finance risks that were seen through high rate of NPF of IRB (Figure

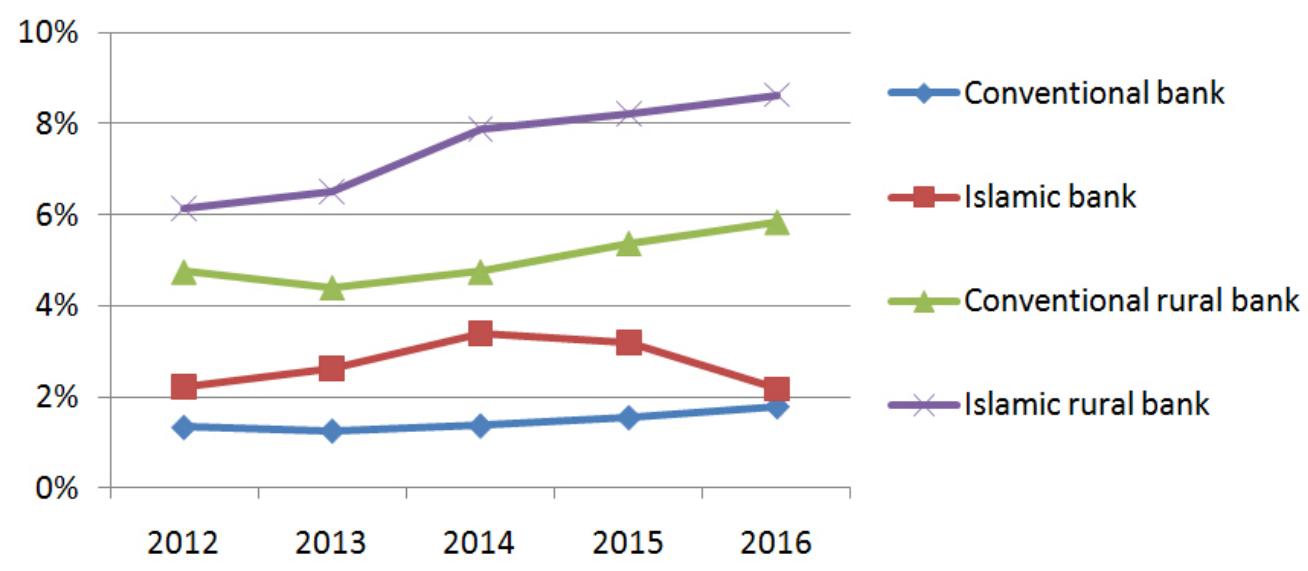

Source : Financial Services Authority

Figure 2 Default Rate in Indonesia 2012-2016

Conventional rural bank had lower LDR if it was compared with other banks. But, NPL which belonged to conventional rural bank was higher than NPL that belonged to conventional bank and also NPF of Islamic bank. It indicates that financing of conventional rural bank had bad or low quality. Even though NPL of conventional rural bank was lower than NPF of Islamic rural bank.But it did not guarantee that financing of conventional rural bank 
IQTISHADIA

12,2

122

had better quality than Islamic rural bank. Otherwise, even though NPF of IRB could occur because of the height of IRB financing, it did not mean that IRB financing had better quality than conventional rural bank.

As common bank, conventional and Islamic rural bank also conducted financing activity in the operational. However, the financing of conventional rural bank in West Sumatera did not had good quality. It was proofed by the enhancement of NPL of conventional rural bank when LDR had decrease. Ineffective selection for customer caused low quality of customer. Low financing quality could occur in ineffective selection process, the high risk of using the fund and returning the fund that was not on time. In this research, low financing quality was depicted by non-refundable and moral hazard. Ineffective customer selection in this research became encourage factor of non-refundable refund because bank was not able to select customer well so that customer with poor quality could access financing as customer with good quality adverse selection). In line with the data, Bakhtiar and Sugema (2012) theoretically stated that sharia bank was more immune toward adverse selection in financing activity so quality of Islamic rual bank financing could be better than conventional one.

Financing by IRB in West Sumatera relatively different with financing by IRB in Indonesia. The different is in the correlation between FDR and NPF of IRB in West Sumatera. Correlation between FDR and NPF of IRB in West Sumatera showed in Figure 3.
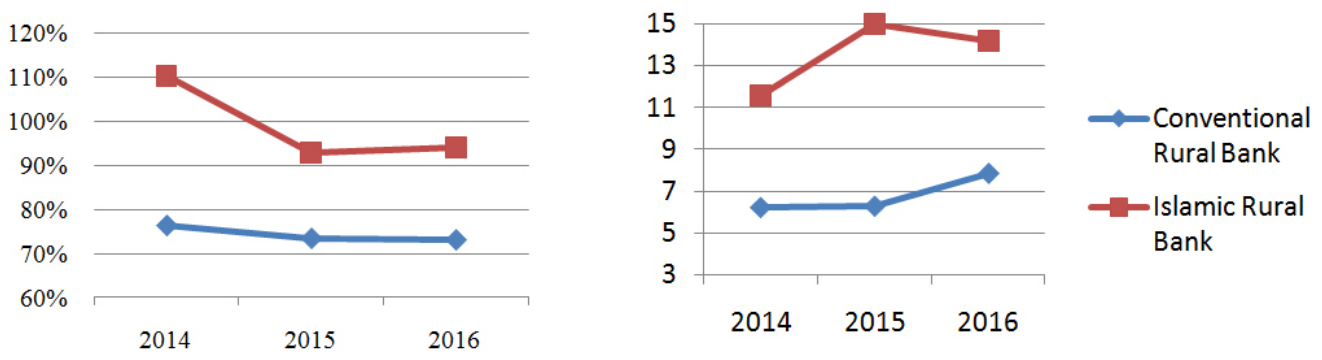

Figure 3 Correlation between financing rateand default rateconventional and Islamic rural bank

Figure 3 showed that IRB have more financing than conventional, so as the default rate. The IRB's NPF is higher than conventional rural bank's NPL, it means that Islamic bank had higher default rate than conventional (Trad et al. 2016). Nevertheless, conventioanl rural bank had negative correlation between financing and default rate. Default rate of conventional 
rural bank has increased when financing has decrease. This data showed that conventional and Islamic rural bank have bad quality of financing, which it may cause shock of bank's performance (Kasmir, 2014; BI, 2007; BI, 2012).

Bad quality of financing defined as the financing which has repayment potention unclear. Asymmetric information in financing may cause bad quality of financing (Hillier \& Ibrahimo, 1993; Akerlof, 1970). Asymmetric information may happened when a party had more information than others (Huda, 2012). In asymmetric information market, customer has information clearly about his project, not like bank. Bank just has known the proportion of customer by risk, but it can't identified the customer's risk.

The credit market was identical to problem of asymmetric information in it. Not only in the conventional credit market, the problem of asymmetric information also occured in the sharia financing market (Anggarwal \& Yousef, 2000). Asymmetric information can be a bank's ignorance of the quality of the customer's business. It cause customer with bad quality of business can get financing like the good one (adverse selection). The customer business quality information unknown to the bank (hidden information) increase the potency of insolvency or default. Asymmetric information also can be inability of bank to control the used of financing by customers (hidden action) which it increase financing risk (moral hazard).

IRB has higher moral hazard risk than BPR. It occured due to sharia financing's risk sharing system that had a high moral hazard risk (Holmstrom, 1979). Moral hazard might occur in the form of fund utilization outside the purpose of financing or moral hazard (Antonio, 2001; Simtowe, 2006). Moral hazard act by customers would increase their default risks. Cause, default risk in the project which financed by financing will be share to default risk of financing. If there was quite a lot of customers conducting moral hazard, it would be possible that the bank's default rate was relatively high.

In the banking world of Indonesia, IRB was bank with the highest NPF or default risk. It indicated that IRB had a tendency to have asymmetric information issues compared to other banks, especially the moral hazard issues. The other hand, conventional rural bank had high NPL too. So there was no guaranty that conventional rural bank customers had no moral hazard. This research want to compared financing between conventional and islamic rural bank so we'll know which bank that had more moral hazard risk.

In this study, analysis was conducted on the factors that prompted moral hazard in conventional rural bank and IRB separately and also 
IQTISHADIA

12,2

124

simultaneously. Based on the results of these factors analysis, strategy would be formulated to be conducted by the IRB and conventional rural bank to suppress the moral hazard. The novelty of this study lies in the analytical method by comparison between conventional and Islamic financing. Beside that this study depend on customers side and bank side, so we can identified the factors by two side.

This study was organized in several sections. The first section was about the reason and the urgency. The next section was the theory and literature review that can supporting this study. Section 3 showed the research method and data. The analysis result and the implications of that result would be discussed in the section 4 . The last section was the conclusions.

\section{LITERATUR REVIEW}

The financing quality was financing that had unclear repayment potency (Fuchita, 2004). The financing quality can be assessed through three things, such as business prospects, customers performance, and customers ability to repayment. Business prospect include the potential of business growth. Customer performance can be seen through profitability, capital structure and sensitivity to market conditions. While the ability to return the fund was seen through the accuracy of the customer in return, the existence of financial information debtor, compliance with the agreement and also the suitabiliy of the use of fund. This research focus on compliance with the agreement which was the suitability of the use of fund (moral hazard).

Moral hazard was a condition where every party of a contract had asymmetric information about the other party actions (Hermalin \& Katz, 1991). Any customer action that may increase financing risk is called moral hazard, like used financing fund to others that not the purpose (side streaming) (Simtowe et al., 2006; Li et al., 2014).

The action of either party on this type of contract will affect the risk and acceptance of all parties involved in the contract (Pauly, 1968; Avery \& Berger 1991). Measures that resulted in the non-fulfillment of obligations as agreed upon, which gave rise to moral hazard issues (Igawa \& Kanatas, 1990; Edelberg, 2004). Variant (2010) defines moral hazard as the condition of the product owner does not know the actions that the consumer may take after he receives the product he or she wants. In the moral hazard insurance market appears to be increased spending on health products by households whose burden is borne by insurance institutions (Wolfe \& Goddeeris, 1991). In the 
moral hazard lending market can occur when customers choose to run more risky projects compared to projects that have been agreed (Avery \& Berger, 1991). Financing with risk sharing system had more moral hazard risk than the other scheme (Holmstrom, 1979; Abedifar et al., 2013).

Based on Sharia compliant, risk sharing system in financing should be reduces moral hazard problems (Abid, 2017). Sharia compliant was not only at the bank side, but also at customers side. The worse literacy of sharia compliant of bank's agents and customer can be the reason of moral hazard in islamic financing. On the other hand, the complicated scheme of financing cause the potency of moral hazard.

Zhang et al. (2015) said that moral hazard was unobservable behaviour. The way to identify it was deep observation. This paper do a difference way to identified the moral hazard. How the customers used their financing fund was the proxy of moral hazard in this paper. Some variables that affect the use of financing funds by customers are age, number of family members, loan size, and gender (Paloma, 2013). Given the moral hazard problems emerging as the impact of the hidden action, the act of mentoring and supervision has become one of the key issues in pressing this problem (Simtowe et al., 2006; Hermes et al., 2005; Sufi 2007; Coleman et al., 2006).

\section{RESEARCH METHOD}

Data used in this analysis was the primary data. The data obtained by in-depth interview to capital financing and investment customers at convenional and Islamic rural bank in West Sumatera. The selection of this province as the location of data collection was based on the relatively high number of NPF IRB in this region. In addition, IRB performance in West Sumatera also showed a substantial decline. There were one hundred working capital financing and investment customers in this research. 50 customers were conventional rural bank customers while the other 50 were IRB customers.

The method analysis used in this journal was logistic regression analysis. Using this method because the dependant variable used was a categorical variable (Firdaus et al., 2011, Juanda, 2009), whereas the dependant variable in this analysis was the customer moral hazard behavior. Score 1 was given to customers who used financing funds in accordance with the financing purpose (not conducting moral hazard). Score o was given to customers who used financing funds for purposes other than the financing purposes (moral hazard). Generally, model on logistic regression analysis was: 
Information:

126 i : observation sample index $(i=1,2, \ldots, n)$

$\mathrm{p}_{\mathrm{i}} \quad$ : moral hazard possibility of i-th observation

$\log :$ natural logarithm (base number of base e)

$\beta_{\mathrm{o}} \quad$ : regression line intercept

$\beta_{1} \quad$ : regression line slope

$X_{\mathrm{i}} \quad$ : explanatory variable

$u \quad$ : error

The result of this analysis was an odd ratio showing the potential for an event to occur in a group to another group. This odd ratio value would be explained in the later discussion, including whether IRB had a greater potential of moral hazard occurence rather than conventional rural bank customers.

\section{Determinants of Moral Hazard}

Assumption of this paper was bank can't to control used financing funds for purpose by customers. Customers characteristic and business characteristic need to identified customer that have more moral hazard potential based on their characteristic or their business. Bank activity need to know how that activity influence moral hazard. As Determinants of moral hazard was in table 1.

Table 1 Determinant of Moral Hazard

\begin{tabular}{|c|c|c|c|c|}
\hline \multicolumn{3}{|c|}{ Variables } & \multicolumn{2}{|l|}{ Explanation } \\
\hline a & & & Konstanta & \multirow{3}{*}{$\mathrm{P}(1)$} \\
\hline \multirow{3}{*}{$\mathrm{Pi}$} & \multirow{2}{*}{ : Moral hazard } & $=1$ & Used financing funds for purpose & \\
\hline & & $=0$ & Used financing funds for other purpose & \\
\hline & \multicolumn{4}{|c|}{ Customers Characteristic } \\
\hline $\mathrm{X}_{1}$ & : Gender & $\begin{array}{l}=1 \\
=0\end{array}$ & $\begin{array}{l}\text { Man } \\
\text { Woman }\end{array}$ & $+/-$ \\
\hline $\mathrm{X}_{2}$ & : Age & & & $+/-$ \\
\hline $\mathrm{X}_{3}$ & : Household size & & & + \\
\hline $\mathrm{X}_{4}^{3}$ & : Spend & & & + \\
\hline $\mathrm{X}_{5}$ & : Total income & & & - \\
\hline \multicolumn{5}{|c|}{ Business Characteristic } \\
\hline $\mathrm{X}_{6}$ & $\begin{array}{l}\text { : Business } \\
\text { condition }\end{array}$ & & & + \\
\hline
\end{tabular}


$\mathrm{X}_{7} \quad$ : The number of financing

$\mathrm{X}_{8} \quad$ : Financing periode

\section{Bank Activity}

$\begin{array}{lll}\mathrm{X}_{9} \quad \text { :Control } & =1 & \text { There is controlling by bank } \\ =\mathrm{O} & \text { There is no controlling by bank }\end{array}$

$=1 \quad$ There is accompaniment

$=0$ There is no accompaniment

$=1 \quad$ Islamic rural bank

$\mathrm{X}_{11} \quad$ : Bank

$=0 \quad$ Conventional rural bank
Is There

Moral

Hazard in

Islamic

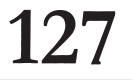

Proxy of moral hazard in this paper refered to Simtowe et al. (2006), Li et al. (2014) and Chan and Thakor, (1987). In that paper, moral hazard was used financing fund for other purpose or bad management of financing. Cause moral hazard was impact of hidden action so controlling and accompanient should be effective to decrease this problem (Simtowe et al., 2006 ; Hermes et al., 2005 ; Repullo \& Suarez, 1999 ; Sufi, 2007; Besanko \& Kanatas, 1993).

\section{Data Characteristic}

Respondent in this research was customer of working capital financing/ loan and investment which amounted 100 respondents. Each respondent had different characteristic that differentiated with others. Customers' characteristic in this research can be seen in Table 2.

Table 2 Data Characteristic

\begin{tabular}{|c|c|c|c|}
\hline Variable & Sub Variable & Moral Hazard & $\begin{array}{l}\text { Non Moral } \\
\text { Hazard }\end{array}$ \\
\hline \multirow{2}{*}{ Gender } & Man & 5 & 56 \\
\hline & Woman & 6 & 33 \\
\hline \multirow[t]{5}{*}{ Age } & $20-35$ & 3 & 32 \\
\hline & $36-45$ & 4 & 31 \\
\hline & $46-55$ & 4 & 22 \\
\hline & $56-65$ & o & 3 \\
\hline & $>65$ & o & 1 \\
\hline \multirow[t]{6}{*}{ Expenditure } & $<2000000$ & 1 & 20 \\
\hline & $2000000-<4000000$ & 9 & 62 \\
\hline & $4000000-<6000000$ & o & 5 \\
\hline & $6000000-<8000000$ & o & 2 \\
\hline & $8000000-<10000000$ & o & 1 \\
\hline & $\geq 10000000$ & 1 & $\mathrm{o}$ \\
\hline \multirow{3}{*}{ Household size } & $1-3$ & 3 & 56 \\
\hline & $4-5$ & 5 & 31 \\
\hline & $>5$ & 3 & 2 \\
\hline
\end{tabular}




\begin{tabular}{|c|c|c|c|c|}
\hline \multicolumn{5}{|l|}{ IQTISHADIA } \\
\hline \multirow[t]{4}{*}{12,2} & \multirow{5}{*}{$\begin{array}{l}\text { Business } \\
\text { condition }\end{array}$} & Very good & 1 & 4 \\
\hline & & Good & 4 & 53 \\
\hline & & Stagnant & 6 & 31 \\
\hline & & Bad & $\mathrm{O}$ & o \\
\hline \multirow{11}{*}{128} & & Very bad & $\mathrm{O}$ & 1 \\
\hline & \multirow{5}{*}{$\begin{array}{l}\text { Business } \\
\text { turnover }\end{array}$} & $<2500000$ & 2 & 15 \\
\hline & & $2500000-<5000000$ & 4 & 38 \\
\hline & & $5000000-<10000000$ & 2 & 24 \\
\hline & & $10000000-<100000000$ & 3 & 7 \\
\hline & & $\geq 100000000$ & $\mathrm{O}$ & 1 \\
\hline & \multirow{5}{*}{$\begin{array}{l}\text { The number of } \\
\text { financing }\end{array}$} & $2000000-<6000000$ & 1 & 26 \\
\hline & & $6000000-<10000000$ & 4 & 22 \\
\hline & & $10000000-<50000000$ & 4 & 37 \\
\hline & & $50000000-<100000000$ & 1 & 4 \\
\hline & & $\geq 100000000$ & 1 & o \\
\hline
\end{tabular}

Table 2 shows that 61 percent of respondents in this research are men. It shows that men dominated demand of financing especially working capital financing and investment. Carter et al. (2007) mentioned structural gap among business of men and women, high trend of sex discrimination from the side of financing deals and high risk aversion level for women became the reason of man dominated financing demand. Even though the business run by women were considered hard to succeed (Buttner \& Rosen, 1998) but bank could not use the reason of sex in limiting financing distribution. The risk of customer still became consideration of bank financing without making sex as one of the risks (Peterson, 1981). Women customers were also considered that had bigger risk in doing moral hazard and 35\% were nonrefundable. Whereas men customer which did moral hazard were only 8 percents and non-refundable men customers were only 34 percents from all men respondents.

Respondents in this research were classified in productive age, in which age range of respondents was between 24 - 67 years old. Between the range, the most respondents was in age range of 20-45 years old that amounted 70 percents. Whereas 30 percents of other respondents were in age group of 46-65 years old. It shows that conventional and islamic rural bank financing customer in West Sumatera were dominated by young customer. The condition should implicate positively toward bank considering customers were in productive age and had big development potential.

Customer with lower age range relatively did not conduct breach of contract. There were only 8.57 percents of customer in age range of 20-35 percent who didmoral hazard. While customer in age range 36-45 years old 
who did moral hazard were 11.42 percents and customer in 46-55 years old were 15.38 percent. Customers in young age also tent to refundable to pay the bank. It was known 66 percent of respondents of 20-35 years old and 68 percent respondents of $36-45$ percents did the payment in refundable. Whereas respondent of 46-55 years old were as refundable customer amounted only 58 percents.

The expenditure in this research was household expenses of the customer every month. 71 percents of respondents had expenditure about Rp 2 Millions - Rp <4 Millions every month, 21 percents had expenditure lower than Rp 2 Millions per month. Whereas 8 percents had expenditure more than Rp 4 Millions per month. This data was enough to represent financing customer condition of conventional and islamic rural bank who were low economic society until middle society. Society of middle and low economic were hard to obtain financing access from general bank because the high risk of default that would emerge. Other than that, these people had asset limitation that could be used as financing guarantee. Most financing customer used vehicle as the guarantee for the proposed financing. The rate of the guarantee that was not too big caused the financing which could obtain by the customer was not in big rate.

Basically, household size dependent represented the basic needs of the family. This variable became very important considering customer priority was completing family's needs. Big number of family dependent was directly proportional with expenditure for basic need and needs toward the financing (Sumarwan, 1993). Inversely proportional with the statement, based on the data, it was known that most respondents had small amount of savings. 59 respondents had dependents of 1-3 people. Whereas respondents with dependents if 4-5 people were 36 respondents and respondents that had dependents more than 5 people amounted 5 respondents. Considering that customers in this research were working capital financing and investment customers, so that the number of dependents might not linear. It could affect the decision of financing application.

Business condition became important thing to be concerned by bank in selecting working capital financing and investment customers. It was because customer's business condition would really affect toward financing quality, especially in refunding. Business condition should have positive relation toward customers' quality. In other words, customer with better business condition was expected to be able to do refund on time and used the financing as the purpose. 
IQTISHADIA

12,2

130

Table 2 shows most respondents had good condition business, 57 respondents. 37 respondents had ordinary condition of business and relatively stable, 5 respondents with very good business and 1 customer with very bad condition of business. Good condition represented business condition with acceptance that tent to increase. If the business income showed significant enhancement, it could be said that the business was in very good condition. If the business income was stable, so the condition was classified in stable or stagnant condition. Bad condition occurred business that the income tent to decrease, but if the decrease was very significant so it caused bankruptcy, so the business was in very bad condition.

Business turnover became indicator of business scale which is run by respondents. The bigger turnover, the bigger business scale was. Based on table 3, it was known that respondents in this research had business turnover less than $\mathrm{Rp} 100$ Millions and only one respondent who had turnover more that Rp 100 Millions. It showed that distributed financing by conventional and islamic rural bank were financing for small micro business sector. As it was written in Law number 20 in 2008 about micro, small and medium enterprises explains business scale criteria, in which turnover business less than Rp 300 Millions were classified as micro business and business with business turnover between Rp 300 Millions and Rp 2.5 Billions were small enterprise. Most Business of these customers were still in livelihood activities level or business which was used as employment opportunity to earn own living, which were selling, farming and rearing. Others were in micro enterprise step, in which respondents had the soul of craftsmen and entrepreneur. These respondents were usually entrepreneurs who had domestic industry even though it was still small scale. Based on table 3 , it was known that most customers who did moral hazard and non-refundable were respondents with turnover between Rp 2.5 Millions until Rp 5 Millions.

The number of financing which accepted by customer was based on asset rate for the guarantee. This effort became bank effort in pressing the risk that might emergence. On the other side, it was the obstacle for customer to obtain bigger financing considering customers were middle economic who had limited asset. Based on the data, it was known the number of customers' financing were about Rp 2 Millions until Rp 100 Millions and only one respondent who accepted more than $\mathrm{Rp} 100$ Millions. 41 respondents accepted the financing between Rp 10 Millions until Rp 50 Millions and in this range, the most non-refundable occurred, who were 13 respondents and 4 respondents did moral hazard. 
From 100 respondents in this research, it was known that 11 respondents used the fund or moral hazard with the purpose of contract financing. In this research, the suitability of the use of funds with the purpose had not to 100 percents because there were found customers who used 100 percents of financing according to financing purpose. Customer was considered using Moral Hazard in Islamic the fund according to purpose when 80 percents of the fund were used for business. But if fund which was used less than 80 percents, the customer was doing moral hazard.

\section{RESULTS AND DISCUSSION}

\section{The Comparison of Moral Hazard in Conventional and Islamic Rural Bank}

This analysis used dummy variables, type of bank. The result show that type of bank variable was considered significant in affecting moral hazard in real level of $5 \%$. It showed that there were difference between moral hazard behavior between conventional and islamic rural bank customers. Type of bank variable had odd ratio value of o.099. It meant tendency of IRB customer to use financing fund was suitable with purpose 0.099 time the tendency of BPR. Smaller odd ratio value less than 1 showed that tendency of conventional rural bank customer to use financing fund as the purpose was bigger than IRB ones. It could be said that IRB customers had bigger opportunity in doing moral hazard rather than conventional ones. This condition contradicted with sharia principle in which each related party in contract was asked to be able to obey agreed contract.

The lack of customers' knowledge about trading rules according to Islamic law and the implementation which had not followed contract regulation should be the main encouragement for this case. The most customers chose financing from conventional because the easiness access or continued previous financing. Whereas customers who had IRB with the reason of sharia obedience were very few because the low of society trust toward conformity of bank operational with sharia principle. People were still consider that sharia bank system was still the same as conventional bank. The issue appeared because in bank operational financing did not explain the contract in a good way to customer so that the the arrangement of agreement was the same as debt contract in conventional bank. Other than that, financing process was done by submitting financing fund to the customer even though it was used murabahah contract. Murabahah contract 
IQTISHADIA

12,2

132

that had constant margin also became the cause of bias for the different of conventional bank in society.

That were many variables that could affect behavior of IRB customers in using the fund if it is compared with conventional rural bank customers. It also encouraged analysis result that IRB customers had bigger potential of moral hazard. Based on the case, IRB should increase effectiveness of customers selection process. In addition, IRB had to more selective in choosing customers. Variables above could become consideration for bank in selecting customer who would receive the financing.

Based on the results of logistic regression analysis, there were different factors effecting moral hazard on three different models. The thing distinguished these three models was the amount of data usage. The first model used conventional and islamicdata collectively, the second model used only conventional data and the third model used IRB data. Differences in the results of logistic regression analysis can be seen in Table 3 .

Table 3 showed the factors that promoted moral hazard on the IRB financing were more than the IRB or the combination of the two banks. In the IRB model, age variable also influenced the customer behavior in utilizing the funds, but this variable had no significant effect on another model. The difference of variable numbers affecting the moral hazard in conventional and islamic rural bank became the reinforcement of the logistic regression results. It indicated that the type of bank significantly affecting the moral hazard.

Table 3 Determinants of Moral Hazard in Conventional and Islamic Rural Bank

\begin{tabular}{lccc}
\hline Variable & $\begin{array}{c}\text { Conventional and } \\
\text { Islamic Rural Bank }\end{array}$ & $\begin{array}{c}\text { Conventional } \\
\text { Rural Bank }\end{array}$ & $\begin{array}{c}\text { Islamic Rural } \\
\text { Bank }\end{array}$ \\
\hline \multirow{2}{*}{ Gender } & -0.026 & -0.980 & 0.983 \\
& $(0.975)$ & $(0.375)$ & $(2.556)$ \\
Age & -0.051 & 0.016 & $-0.172^{*}$ \\
\multirow{2}{*}{ Total income } & $(0.950)$ & $(1.016)$ & $(0.842)$ \\
& -0.691 & -0.484 & -0.574 \\
Household size & $(0.501)$ & $(0.617)$ & $(0.563)$ \\
& -0.280 & -0.172 & -0.193 \\
& $(0.756)$ & $(0.842)$ & $(0.825)$
\end{tabular}




\begin{tabular}{|c|c|c|c|}
\hline Variable & $\begin{array}{l}\text { Conventional and } \\
\text { Islamic Rural Bank }\end{array}$ & $\begin{array}{l}\text { Conventional } \\
\text { Rural Bank }\end{array}$ & $\begin{array}{l}\text { Islamic Rural } \\
\text { Bank }\end{array}$ \\
\hline \multirow{2}{*}{ Spend } & -0.272 & -0.967 & -0.293 \\
\hline & $(0.762)$ & $(0.380)$ & $(0.746)$ \\
\hline \multirow{2}{*}{ Business condition } & $-1.470^{*}$ & -1.448 & $-2.638^{*}$ \\
\hline & $(0.230)$ & $(0.235)$ & (0.071) \\
\hline \multirow{2}{*}{$\begin{array}{l}\text { The number of financ- } \\
\text { ing }\end{array}$} & $-1.190^{*}$ & -0.647 & $-2.220^{*}$ \\
\hline & $(0.304)$ & $(0.524)$ & (0.109) \\
\hline \multirow{2}{*}{ Financing periode } & $-0.114^{*}$ & $-0.103^{*}$ & -0.187 \\
\hline & (o.894) & $(0.902)$ & (o.803) \\
\hline \multirow[b]{2}{*}{ Bank } & $-1.988^{*}$ & & \\
\hline & $(0.137)$ & - & - \\
\hline \multirow{2}{*}{ Accompaniment } & 1.204 & 22.769 & 0.404 \\
\hline & $(3 \cdot 334)$ & (7732401872) & $(1.498)$ \\
\hline \multirow{2}{*}{ Constanta } & $46.052^{*}$ & $41.309^{*}$ & $68.715^{*}$ \\
\hline & $(1.000 \mathrm{E}+20)$ & $(8.719 \mathrm{E}+17)$ & $(6.960 E+29)$ \\
\hline
\end{tabular}

Age variable significantly affected the moral hazard on IRB with odd ratio of 0.842 . An odd ratio less than 1 indicated that younger customers were more likely not to conduct side streaming than older customers. In other words, younger customers tended to use financing funds in accordance with the financing purposes. More business experiences for older customers was one of the driving factors of this occurence. With more experiences meant that older customers were able to manage their business finances better. This experiences also caused older customers to be more likely to use their financing for other business interests that would increase the default risk. On the contrary, younger customers were relatively new to start a business. These customers didn't dare to take a big risk by using the funds for other purposes.

The age variable significantly affecting the moral hazard only on the IRB model, while this variable insignificantly affecting the moral hazard on the other model. This suggested that the utilization of age variable to predict customers compliance in using the funds according to its purposes was quite weak. This variable might be significantly affecting the IRB model due to the high diversity of IRB customer age and the large number of moral hazard in IRB customers. 
IQTISHADIA

12,2

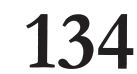

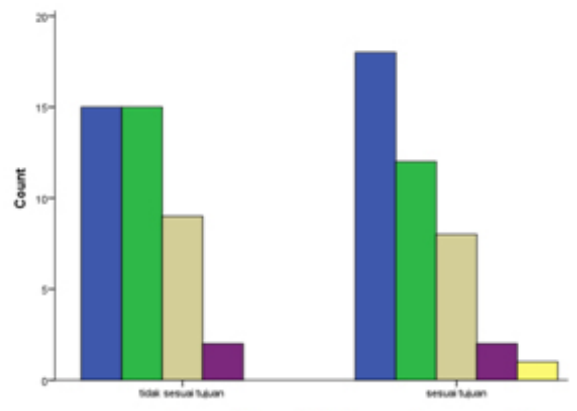

Conventional and islamic rural bank

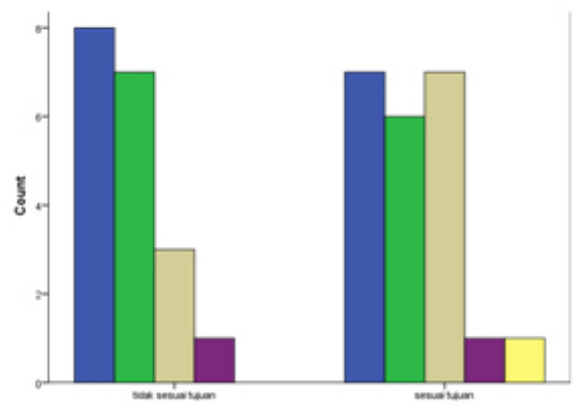

Conventional rural bank

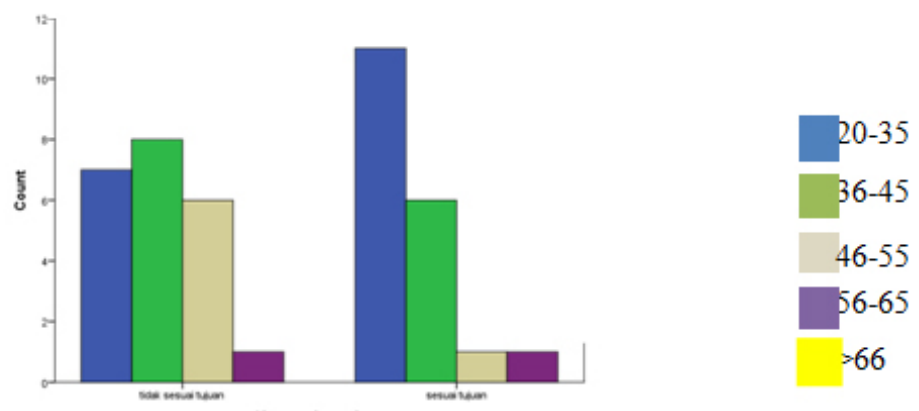

Islamic ruralbank

Figure 4 Moral hazard based on age

Business condition was significantly affecting moral hazard inIRBand both conventional and Islamic rural bank in general. This indicated that business condition variable was one of the variables that had a major impact on the customer's decision to use the funds. Customers with relatively poorer business conditions used their financing funds in accordance with it purposes, such as business capital or investment. This can be concluded by the business condition odd ratio value that less than one in all analyzed models.

This meant that customers with worse business conditions were relatively more obedient on the agreed contract than customers with better business conditions. Customers with worse business conditions had a greater business risk rather than customers with better business conditions. The financing funds utilization which was not in accordance with its purposes would increase the default risk of the customers. Based on the case, customer with bad business condition rationally would tend to avoid moral hazard behavior so that the risks did not increase.

Customer with worse business condition relatively needed more capital to improve business condition than customer with better condition. Thus, financing fund which was received by customer with worse business condition would be maximized to be able to improve business condition. Otherwise, 
customer with better business condition tent to had stable capital. Therefore, financing fund could be used flexibly for other importance.

Is There

Moral

Significant size of financing affected customer's decision in using financing fund in IRB or in general. Odd ration which was less than one showed that customer with smaller financing tent to use funds according to the purpose than customer with bigger financing. Customer with lower financing was relatively dominated by customers of micro business scale. Capital for developing the business was also big relatively. Therefore, financing that was proposed to bank rationally would be used all to develop the business. Otherwise, customer with bigger financing reception had higher asset well. Proposed financing only aimed to cover small part of business importance which was complementary.

Beside, basically customer had known the needs of venture capital fund. However, proposed financing was often bigger than the needs. The excess find was used to fulfill other needs of the customer outside the needs of the business. On the other hand, customer with smaller financing tent to use funds according to the purpose cause they took larger equity positions in their own business. So, the financing fund used to complete the capital that they need, which the size was smaller than capital by them. The customer's willingness to invest in his own business can serve as a signal of their business quality (Leland \& Ryle 1976).

In IRB model partially, this variable was known significantly in affecting moral hazard. Taking into account that the amount of financing from IRB used murabahah contract or buy and sell, thus, it should be moral hazard because big funding application could be maintained, but the time deputed to customer to be able to buy things that were needed. The system opened the occurance of moral hazard in financing by IRB.

Therefore, the use of wakalah contract in murabahah financing needed reviwed because moral hazard potential might appear from the contract. If replacement of wakalah was considered hard, then effective supervision was needed as solution in pressing moral hazard value. The supervision was done to make sure used fund was used according to the propose purpose of the fund. In supervision process, it needed sanction toward infringement which was done by customer. This sanction is needed to me managed and agreed upon both parties in contract.

Basically, it did not only occur in IRB customer, but also it had been found in BPR customer. However the numbers of the occurrence showed 
IQTISHADIA

12,2

Variable of significant duration of financing affected moral hazard in three models which were used in this research. It meant that financing which was proposed by customer could become risk indicator of financing fund usage by the customer. Odd ratio value that was less than one showed that financing customer with shorter financing duration tent using financing fund according to the purpose. It could be said that the longer duration of financing occurred, the bigger opportunity for customer to do moral hazard.

Customer with longer duration of financing had perception that there were many enough time for customer in returning financing fund. Therefore, customer could use financing fund to fulfill other needs or make as capital for other business so that it could produce bigger profit. Otherwise, customer with shorter duration of financing had to return financing fund in short time relatively. So that it would be very at risk if the customer used financing fund that was not according to the purpose. The used of financing funds based on duration of financing was in Table 4.

Table 4 The used of financing funds based on duration of financing

\begin{tabular}{|c|c|c|c|c|c|c|c|c|}
\hline \multirow{2}{*}{ Bank type } & \multirow{2}{*}{ Suitability with purpose } & \multicolumn{6}{|c|}{ Duration of financing (month) } & \multirow{2}{*}{ Total } \\
\hline & & 12 & 18 & 24 & 30 & 36 & 60 & \\
\hline \multirow{3}{*}{$\begin{array}{l}\text { Conventional } \\
\text { and Islamic } \\
\text { rural bank }\end{array}$} & $\begin{array}{l}\text { Suitable with the } \\
\text { purpose }\end{array}$ & 7 & 4 & 26 & 1 & 3 & o & 41 \\
\hline & Not suitable & 3 & 2 & 22 & o & 13 & 1 & 41 \\
\hline & Total & 10 & 6 & 48 & 1 & 16 & 1 & 82 \\
\hline \multirow{3}{*}{$\begin{array}{l}\text { Conventional } \\
\text { rural bank }\end{array}$} & $\begin{array}{l}\text { Suitable with the } \\
\text { purpose }\end{array}$ & 4 & o & 15 & 1 & 2 & o & 22 \\
\hline & Not suitable & 1 & 1 & 9 & o & 7 & 1 & 19 \\
\hline & Total & 5 & 1 & 24 & 1 & 9 & 1 & 41 \\
\hline \multirow{3}{*}{$\begin{array}{l}\text { Islamic rural } \\
\text { bank }\end{array}$} & $\begin{array}{l}\text { Suitable with the } \\
\text { purpose }\end{array}$ & 3 & 4 & 11 & o & 1 & $\mathrm{O}$ & 19 \\
\hline & Not suitable & 2 & 1 & 13 & o & 6 & O & 22 \\
\hline & Total & 5 & 5 & 24 & 0 & 7 & 0 & 41 \\
\hline
\end{tabular}

\section{Moral Hazard in Islamic View}

Islam strictly orders all Muslims to comply with contracts or agreements that have been agreed upon. This has been clearly defined in the Qur'an and the 
Sunnah of the Prophet. As in Q.S Al-Maidah verse 1, which means, "O you who believe, fill the contracts...”. This verse clearly commands the Muslims to fulfill the contracts or agreements they have agreed upon.

Referring to the verse, it's clear that moral hazard is against the Islamic sharia. Moral hazard behavior clearly violates the agreements that have been agreed upon. Whereas the purpose of the fund utilization is for certain business interests, but in the end the fund is not fully for this purpose. This means that moral hazard performers have denied the contract that has been agreed by the bank. In Islamic law, someone who denies a promise or agreement is called a hypocrite. As the words of Rasulullah (may peace be upon him) narrated by Muslim, which means "There are three hypocritical signs: when he speaks he lies, when he gives a promise he breaks it, and when he is trusted he is treacherous."

Moral hazard behavior may be classified into dholim behavior conducted by the customer against the bank. Moral hazard behavior will increase the default risk of financing beyond the bank's prediction. Cause it will be a inhibition to customer to fulfill the obligation, such as repayment (Igawa \& Kanatas, 1990; Edelberg, 2004). It will cause higher risk (Pauly, 1968; Avery \& Berger, 1991) and difficulties for the bank to predict the level of financial risk that influences the bank's policy to determine the effective steps in anticipating problems caused by the moral hazard. In Q.S Ali-I'mran verse 57 Allah says, "... and Allah does not like the wrongdoers." Based on postulates, it is quite clear that moral hazard behavior is prohibited in Islam.

\section{Strategy}

McCaskie (1999) said that moral hazard was a serious problem which was unarrangeable. Moral hazard would be there as long as asymmetric information and could be worst by modern banking. Nonetheless, it is needed strategies which could be done by bank to be able to pressure the numbers of moral hazard in financing. The strategies were selection effectiveness, accompaniment and supervision.

Selection conducted by Bank toward financing should be able to give information related to customer to bank overall. Complete information was expected to be able to give depiction of customers' risk to bank so that bank could press the problem from imbalance information. Selection which was done only by using financing fund tract record of customer (BI checking) and guarantee as benchmark for the amount of financing. They were considered not effective in guaranteeing good financial quality. The selection should encompass customer's business and customer's social economic condition. 
IQTISHADIA

12,2

138

Because moral hazard was affected by customer's characteristic and business characteristic, thus, bank should make both as customer selection docus. Between both characteristics, business characteristic was considered to affect more toward returning bank's fund by the customer (DeVaney \& Lytton, 1995). the improvement of selecting system became important because business characteristic could not be seen from BI checking process. Bank should do obtain dept information from customer and do the survey of customer's business. Thus, bank would have clear depiction about risk of customer's business.

Beside BI checking, customer selection process could be conducted by arranging good contract. Terms and conditions with good management in contract would enable bank to receive complete information about customer (Chiappori \& Salanie, 2000; Igawa \& Kanatas, 1990). Good Terms and conditions will would also become the basic for bank to limit or refuse financing for customer who had high relative risk (credit rationing) (Hillier \& Ibrahimo, 1993). Product differentiation with terms according to ratio level would make bank could project more risk portfolio and saver portfolio. One of product diversification form was by diversifying interest rate level or profit sharing. Stiglitz and Weiss (1981) revealed that interest rate or profit sharing affected toward risk in financing including the risk of asymmetric information. Interest rate of sharing profit could order customers based on the risk level (press adverse selection) and could affect customers' behavior (press moral hazard).

Supervision became one of important efforts in increasing financing quality especially in sharia banking. In which, analysis result showed ineffective supervision which was done by bank in pressing moral hazard or the usage of fund which was not accordance with the purpose. Other than that, customer had not felt the supervision from bank. The visit of bank to business location or house of customer only aimed to ask for payment and financing. However, from the bank's perspective, those ways were supervision they did.

Event though it was known bank as supervision, but the reality said that it was not effective to increase financing quality. It was proofed with the high numbers of moral hazard. There was no firmaction from bank toward customer's behavior that could increase financing risk became one of cause ineffectiveness supervision. Thus, clear sanction was needed in contract and it needed to understand by both parties so that there were no financing problem. 
Dam and Koetter (2012) showed that supervision could be mitigate moral hazard if the intervention aim directly at the bank's management. The other alternative was involve outright restriction of bank's business. Bank have to select the supervisory interventions that they should did. Multiple interventions of bank may even foster moral hazard problem.

Beside implementing the sanction, supervision could also be done by using group financing program. Implementing the program could reduce cost of bank's supervision, but it gave effective result. In grouping financing, the risk of customer's behavior of moral hazard would impact to all group member. So that the supervision would become the responsiility of all members in group financing (Ghatak \& Guinnane, 1999).

Business condition of customer became factor that affected moral hazard. Bad business condition would be bad result toward financing quality of bank. Therefore, accompaniment of bank in maintaining good business condition of customer became the most important thing, especially for customer who felt first experience in business. Bank should have enough understanding related to business management so the accompaniment could be done well.

In financing of BPR and IRB in West Sumatera, customer's financing did not feel business accompaniment from bank. Independently they run and improve their worse business condition. One of financing customer of work capital in IRB had bankruptcy even revealed that he had to return the fund even though the business had not run anymore. It was because financing scheme which was used by IRB in West Sumatera was sell and by, not sharing profit. With sell and buy scheme, bank did not feel to have responsibility in maintaining customers' business as it had done by bank with sharing profit scheme.

\section{CONCLUSION}

This research tries to analyze the potential of moral hazard in IRB. Analysis is conducted by comparing customer's condition of IRB and BPR conventional. The result of logistic regression analysis shows that IRB has bigger potential in having moral hazard problem rather than BPR conventional. The lack of understanding of customers about transaction regulation in sharia, ineffective selection method and not firm sanction and supervision of bank also become encourage factor of high potential of moral hazard which are business condition, the amount of financing, the duration of financing. To be able to push moral hazard value, bank can conduct effective selection, supervision and accompaniment. 
IQTISHADIA

12,2

140

\section{References}

Abid, M.M.S., (2017). Moral hazard and risk taking incentives in Islamic banks, does franchise value matter!. International Journal of Islamic and Middle Eastern Finance and Management. 10 (1).

Akerlof, G.A. (1970). The market for "lemons": quality uncertainty and the market mechanism. The Quarterly Journal of Economics 84 (3): 488-500

Anggarwal, R., Yousef, T. (2009). Islamic banks and investment financing. Journal of Money, Credit and Banking, 32 (1): 93-120.

Antonio (2001). Bank Syariahdari Teorike Praktik. Jakarta (ID): Gema Insani.

Armanto, B. Fenomena credit crunch dalam pasar kredit dan implikasinya terhadap intermediasi perbankan Indonesia: analisis empiris perbankan Indonesia sebelum dan setelah periode krisis. [disertasi]. Depok : Universitas Indonesia

Avery, R.B., Berger, A.N. (1991). Loan commitments and bank risk exposure. Journal of Banking and Finance 15 : 173-192

Bakhtiar, T., Sugema, I. (2012). Masalah informasi asimetrik dalam sistemper bankan syariah: adverse selection problem. eprints. unisbank.ac.id

Besanko, D., Kanatas, G . (1993). Credit market equilibrium with bank monitoring and moral hazard. The Review off Financial Studies 6(1): 213-232

[BI] Bank Indonesia. (2007). Peraturan Bank Indonesia Nomor: 9/17/ PBI/2007 tentang Sistem Penilaian Tingkat Kesehatan Bank Perkreditan Rakyat Berdasarkan Prinsip Syariah.[Internet]. [diunduh: 2017 Maret 8]. Tersediapada: http://www.bi.go.id

Buttner, E.H., Rosen, B. (1988). Bank loan officers' perceptions of the characteristics of men, women, and successful entrepreneurs. Journal of Business Venturing 3(3):249-258. doi : 0883-9026(88)90018-3

Carter, S., Shaw, E., Lam, W., Wilson, F. (2007). Gender, enterpreneurship, and bank lending : the criteria and processes used by bank loan officers in assessing applications. Entrepreneurship Theory and Practice 31(3): 427-444. doi : j.1540-6520.2007.00181.x

Chan, Y.S., Thakor, A.V. (1987). Collateral and competitive equilibria with moral hazard and private information. The Journal of Finance 42(2):345-363 
Chiappori, P.A., Salanie, B. (2000). Testing for asymmetric information in insurance markets. Journal of Political Economy. 108 (1):56-78.

Cressy, R., Toivanen, O. (2001). Is there adverse selection in the credit market?.Venture Capital: International Journal of Entrepreneurial Finance.3 (3): 215-238.

Dam, L., Koetter, M. (2012). Bank bailouts and moral hazard: evidence from Germany. The Review of Financial Studies. 42 (8): 2343-2380.

DeVaney, S.A., Lytton, R.H. (1995). Household insolvency: a review of household debt repayment, delinquency, and bankruptcy. Financial Services Review.42 (2): 137-156.

Edelberg, W. (2004). Testing for adverse selection and moral hazard in consumer loan markets. FEDS Working Paper No 2004-09

Firdaus, M., Harmini, Farid, M.A. (2011). Aplikasi Kuantitatif Untuk Manajemen dan Bisnis. Bogor (ID): IPB Press.

Ghatak, M., Guinnane, T. (1999). The economics of lending with joint liability: theory and practice. Journal of Development Economics.60(1):195-228.

Hermes N, Lensink R, Mehrteab HT. 2005. Peer monitoring, social ties and moral hazard in group lending programs: evidence frim Eritrea. World Development 33 (1): 149-169. doi: 10.1016/j.worlddev.2004.09.001

Hillier, B., Ibrahimo, M.V. (1993). Asymmetric information and model of credit rationing. Bulletin of Economic Research.45 (4): 277-304.

Holmstrom, B. (1979). Moral hazard and observability. The Bell Journal of Economics,10 (1): 74-91.

Huda, A.N. 2012. The development of Islamic financing scheme for SMEs in a developing country: the Indonesian case. Procedia: Social and Behavioral Science 52:179-186

Igawa, K., Kanatas, G. (1990). Asymmetric information, collateral, and moral hazard.The Journal of Financial and Quantitative Analysis. 25(4):69-490.

Juanda, B. (2009). Ekonometrika: PemodelandanPendugaan. Bogor (ID): IPB Press

Kasmir (2014). Bank dan Lembaga Keuangan Lainnya. Jakarta : RajaGrafindo

Leland, H.E., Pyle, D.H. (1976). Informational asymmetries, financial structure, and financial intermediation. The Journal of Finance 32(2): 371-387 
IQTISHADIA

12,2

142

Li, S., Yang, Y., Zongfang, Z. (2014). Research on impact of moral hazard on individual credit risk. Procedia Computer Science 31(1): 577-586

McCaskie, P. (1999). Asymmetric information, adverse selection and moral hazard in the banking industry. Working Paper 1999(04).

Nuryakin, C., Warjiyo, P. (2006). Perilaku penawaran kredit bank di Indonesia: kasus pasar oligopoli periode Januari 2001-Juli 2005. Buletin Ekonoomi Moneter dan Perbankan

Paloma, C. (2013). Advese selection dan moral hazardpada skim kreditlembagakeuanganmikroagribisnis (LKM-A) PUAP di Kota Padang. [tesis]. Bogor (ID): IPB

Pauly, M.V. (1968). The economics of moral hazard: comment. The American Economic Review 58(3):531-537

Peterson, R.L. (1981). An investigation of sex discrimination in commercial banks' direct consumer lending. The Bell Journal of Economics 12(2): 547-561. doi : 10.2307/3003571

Repullo, R., Suarez, J. (1999). Entrepreneurial moral hazard and banking monitoring: a model of credit channel. European Economic Review 44(10): 1931-1950. doi:10.1016/Soo14-2921(99)ooo69-0

Simtowe, F., Zeller, M., Phiri, A. (2006). Determinants of moral hazard in microfinance: empirical evidence fromjoint liability lending programs in Malawi. African Review of Money Finance and Banking :5-38.

Stiglitz, J.E., Weiss, A. (1981). Credit rationing in markets with imperfect information, part II: constraints as incentive devices.The American Economic Review.71(3):393-410.

Sumarwan, U. (1993). Socioeconomic and psycological variables influencing household debt. [disertasi]. Ames:Iowa

Taswan(2011). Konsekuensi informasi asimetrik dalam perkreditan dan penanganannya pada lembaga perbankan.Fokus Ekonomi. 10(3):226-234.

Trad, N., Trabelsi, M.A., Goux, J.F. (2016). Risk and profitability of Islamic banks: a religious deception or an alternative solution. European Research on Management and Business Economics. 23 (1): 40-45.

Varian, H.R. (2010). Intermediate Microeconomics: A Modern Approach . New York (US): W.W. Norton \& Company 
Wolfe, J.R, Goddeeris, J.H (1991). Adverse selection, moral hazard, andd Is There wealth effects in the medigap insurance market. Journal of Health Economics. 10 (4): 433-459

Moral Hazard in

Zhang, D., Cai, J., Dickinson.D.G., Kutan, A.M., (2015). Non-performing loans, moral hazard and regulation of the Chinese commercial Islamic banking system. Journal of Banking and Finance. 63: 48-6o. 